\title{
COMPARATIVE STUDIES ON REMEDIATION TECHNIQUES IN LABORATORY OF SOILS CONTAMINATED WITH LIQUID PETROLEUM PRODUCTS
}

\author{
Maria Popa $^{1 \mathrm{a}}$, Loredana Irena Negoita $^{1}$ \\ ${ }^{1}$ Petroleum-Gas University of Ploieşti, Bd. Bucureşti, no. 39, postal code \\ 100680, mariapopa2007@gmail.com, Romania
}

\begin{abstract}
Soil pollution by oil products is one of the most obvious environmental problems that Romania has been facing in recent years. Given the alert pace of use of petroleum products and for meeting energy needs, it is noted that both in Romania and abroad there are reported accidental oil spills to soil or water, which causes economic, social and environmental issues. In this paper we propose a review of the particularities of soil pollution with liquid petroleum products and opportunities for remediation. The analysis of remediation processes of soils contaminated with liquid petroleum products highlights the advantages and disadvantages of each method. The analyzed samples were subjected to thermal remediation methods: combustion and thermal desorption and one of the chemical processes, succesive extraction with solvents.

The results of these experimental data allow us to conclude that the used method is efficient and can be applied at industrial level with high efficiency.
\end{abstract}

Keywords: liquid petroleum products, pollution, remediation

\section{Introduction}

The paper aims to emphasize the particularities of remediation of soils that were contaminated with liquid petroleum products in the laboratory.

Several studies show the ways of choosing a method of remediation of soils that were contaminated with liquid petroleum products. For the areas polluted with these kinds of substances, measures should be taken right after the incident. Depending on the physical properties of the soil and of the other products that pollute the soil, remediation depends on the time the pollutant is on and in the soil. The analysis of remediation processes of soils that were contaminated with liquid petroleum products shows the advantages and disadvantages of each method itself.

In the present paper there were applied thermal methods of remediation in the laboratory: combustion and thermal desorption and successive extraction with solvents using petroleum ether and benzene. There authors are concerned about testing multiple types of soils [1-4].

\section{Experimental part}

For the analysis, there were chosen samples from an area with liquid petroleum products that have been discharged on the soil for a longer period of time. There were taken samples of contaminated soil that were homogenized and analyzed using three methods. There were also taken samples of uncontaminated, fresh soil from the surroundings of the polluted area, that were called witness samples and that were also subject to decontamination methods. 
The results represent an average of all of the determinations that were made.

The remediation of soils that were contaminated with petroleum products through combustion method means burning the pollutant with the oxygen from the air and this method is recommended for the soils that were polluted with heavy petroleum products. By burning the mixture of soil and petroleum products, it is done not only the full elimination of the pollutant, but also the organic material from the soil structure. The installation in which the experimental determinations were done, regarding the remediation of soils samples through combustion method is shown in figure 1[5].

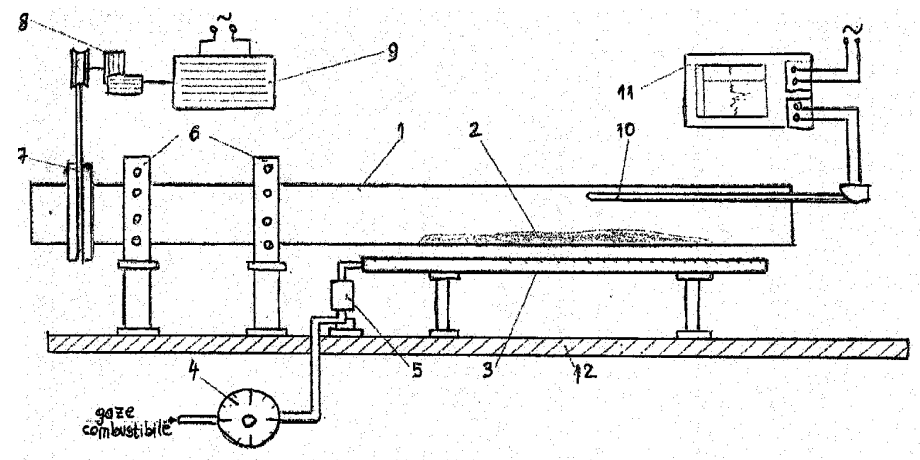

Figure 1. Decontamination by combustion installation scheme

1- combustion tube; 2 - soil sample subjected to combustion; 3 - burner gas; 4 - combustible gas meter; 5 - fuel-air mixing system; 6 - supporting bearings; 7 - drive system combustion tube; 8 - speed reducer; 9 - electric motor drive; 10 - sheathed thermocouple, 11 - meter and recording; 12 - support system

Thermal desorption is recommended for soils contaminated with volatile or semivolatile compounds. The remediation process through thermal desorption has two different stages. The first stages means volatilization of pollutants by heating the contaminated soils, while the second stage means treatment of the resulted gases, in order to separate and concentrate the pollutants.

The installation for decontamination method through thermal desorption is presented in figure $2[5]$.

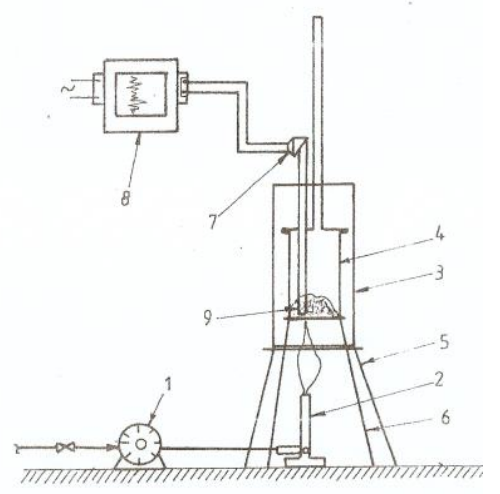

Figure 2. Decontamination by thermal desorption installation scheme

1 - gas meter; 2 - gas lamp; 3 - heating jacket; 4 - metal crucible; 5 - heating mantle support; 6 - support crucible; 7 - thermocouple; 8 - temperature recorder; 9 - soil sample subjected to thermal desorption. 
The extraction of petroleum product through the contaminated soils was done with the Soxhlet apparatus. There were used two solvents, petroleum ether and benzene and there was a successive extraction with those solvents. In figure 3 it is presented the Soxhlet apparatus in which the extractions were made [5].

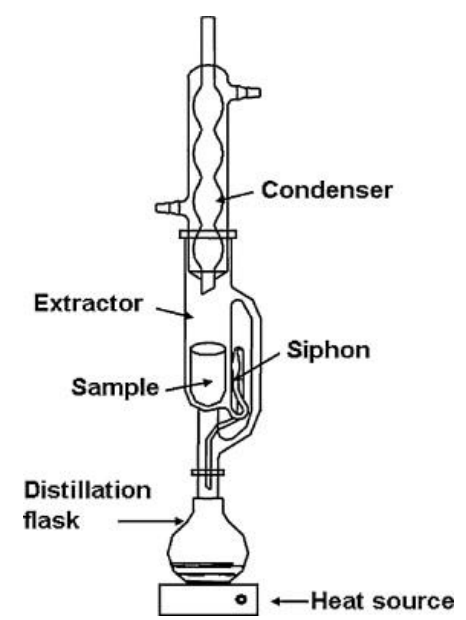

Figure 3. Soxhlet apparatus

\section{Results and Discussion}

In Tables 1-3 are the results obtained after the application of the three methods for decontamination.

Table 1. Results after combustion

\begin{tabular}{|c|c|c|c|}
\hline No. & Specified size & Clean soil sample & $\begin{array}{l}\text { Polluted soil } \\
\text { sample }\end{array}$ \\
\hline 1. & $\begin{array}{l}\text { Quantity of polluted } \\
\text { soil, } g\end{array}$ & - & 100 \\
\hline 2. & $\begin{array}{c}\text { Quantity of clean soil } \\
\text { for combustion, } g\end{array}$ & 100 & - \\
\hline 3. & $\begin{array}{c}\text { Quantity of soil after } \\
\text { combustion,g }\end{array}$ & 98 & 81 \\
\hline 4. & $\begin{array}{c}\text { Quantity of organic } \\
\text { material,g }\end{array}$ & 2 & 2 \\
\hline 5. & $\begin{array}{c}\text { Quantity of petroleum } \\
\text { products+organic } \\
\text { material,g }\end{array}$ & & 19 \\
\hline 6. & $\begin{array}{c}\text { Quantity of petroleum } \\
\text { product, } g\end{array}$ & - & $19-2=17$ \\
\hline 7. & $\begin{array}{l}\text { Petroleum product, } \\
\quad \% \text { mass }\end{array}$ & - & 17 \\
\hline 8. & $\begin{array}{c}\text { Degree of } \\
\text { remediation, } \%\end{array}$ & - & 100 \\
\hline
\end{tabular}


Table 2. Results after thermal desorption

\begin{tabular}{|c|c|c|c|}
\hline No. & Specified size & Clean soil sample & $\begin{array}{l}\text { Polluted soil } \\
\text { sample }\end{array}$ \\
\hline 1. & $\begin{array}{l}\text { Concentration pollutant, } \\
\qquad \mathrm{C}_{0}, \%\end{array}$ & 0 & 17 \\
\hline 2. & Temperature, ${ }^{\circ} \mathrm{C}$ & $300-400$ & $300-400$ \\
\hline 3. & Desorption time, minute & 30 & 30 \\
\hline 4. & Quantity of sample, $\mathrm{g}$ & 100 & 100 \\
\hline 5. & $\begin{array}{c}\text { Quantity of sample after } \\
\text { desorption, } g\end{array}$ & 98 & 86 \\
\hline 6. & Organic material lost, \% & 2 & 2 \\
\hline 7. & $\begin{array}{c}\text { Organic material lost + } \\
\text { petroleum product lost, } \\
\text { after desorption, \% }\end{array}$ & - & 14 \\
\hline 8. & $\begin{array}{c}\text { Quantity of petroleum } \\
\text { product, \% }\end{array}$ & - & $14-2=12$ \\
\hline 9. & Degree of remediation, $\%$ & - & 70.6 \\
\hline
\end{tabular}

Table 3. Results after succesive extraction

\begin{tabular}{|c|c|c|c|}
\hline No. & Specified size & Clean soil sample & $\begin{array}{c}\text { Polluted soil } \\
\text { sample }\end{array}$ \\
\hline 1. & Quantity of sample, g & 10 & 10 \\
\hline 2. & $\begin{array}{c}\text { Quantity obtained with } \\
\text { petroleum ether, } g\end{array}$ & 0.019 & 0.35 \\
\hline 3. & $\begin{array}{c}\text { Quantity obtained with } \\
\text { benzene, g }\end{array}$ & 0.036 & 0.48 \\
\hline 4. & $\begin{array}{c}\text { Total quantity after } \\
\text { extraction,g }\end{array}$ & 0.055 & 0.55 \\
\hline 5. & $\begin{array}{c}\text { Organic material lost after } \\
\text { extraction, \% mass }\end{array}$ & 0.55 & $8.3-0.55=7.75$ \\
\hline 6. & $\begin{array}{c}\text { Petroleum product lost } \\
\text { after extraction, \% mass }\end{array}$ & - & 45.6 \\
\hline 7. & Degree of remediation,\% & - & \\
\hline
\end{tabular}

All results are presented in Table 4 for comparison. 
Table 4. The results obtained through the three methods

\begin{tabular}{|c|c|c|c|}
\hline \multicolumn{2}{|c|}{ Organic material lost, \% mass } & $\begin{array}{c}\text { Petroleum product } \\
\text { lost, \% mass }\end{array}$ & $\begin{array}{c}\text { Degree of } \\
\text { remediation, \% } \\
\text { mass }\end{array}$ \\
\hline Extraction & 0.55 & 7.75 & 45.6 \\
\hline Combustion & 2 & 17 & 100 \\
\hline $\begin{array}{c}\text { Thermal } \\
\text { desorption }\end{array}$ & 2 & 12 & 70.6 \\
\hline
\end{tabular}

\section{Conclusions}

The soils that were decontaminated through thermal methods have their structure and composition affected because of the high temperatures they were exposed to.

By fully eliminating the organic part because of the combustion remediation and by the major transformation that the soil suffers because of thermal desorption, the germinative potential of the specific soil is reduced.

For the analyzed samples, without knowing the pollutant concentrations, it was considered that the combustion method is $100 \%$ efficient and it was possible to establish a pollutant concentration in the initial samples (17\%). The reduced remediation degree for thermal desorption (70.6\%) can be explained because without knowing the nature of the pollutant (structure, physical properties) it is possible that the maximum applied temperature of $400{ }^{\circ} \mathrm{C}$ to be to low (compared with the $800{ }^{\circ} \mathrm{C}$ temperature applied for combustion) for getting rid of the heavier products that exist.

By subjecting the same sample to remediation through successive extractions with solvents, it was found that a smaller concentration of pollutant is obtained, compared to the results that were obtained through thermal methods. This thing can be explained through the fact that it may be possible the usage of a third or even fourth solvent.

\section{References}

1. Popa, M. Comparative studies on remediation techniques in laboratory of soils contaminated with oil products, (2014), Land Reclamation, Earth Observation \& Surveying, Environmental Engineering, Agriculture for Life, Life for Agriculture, III, Bucharesti, p. 13-16.

2. Popa, M. Laboratory studies on the simulation of accidental pollution of soils,(2015), Land Reclamation, Earth Observation \& Surveying, Environmental Engineering, Agriculture for Life, Life for Agriculture, IV, Bucharest , p. 116-119.

3. Yi, Y.M., Park, S., Munster, C., Kim, G., Sung, K. Changes in Ecological Properties of Petroleum Oil-Contaminated Soil After Low-Temperature. Thermal Desorption Treatment, Water, Air \& Soil Pollution, 227, (2016), p. 108.

4. Ghervase, L., Dontu, S., Savastru, D. - Evaluation of thermal treatment in decontaminating soils polluted with crude oil, 14th International Multidisciplinary Scientific GeoConference SGEM 2014, www.sgem.org, SGEM2014 Conference Proceedings, ISBN 978-619-7105-14-8 / ISSN 1314-2704, June 19-25, 2014, Book 3, Vol. 2, p. 123-130.

5. Patrascu, C., Negoita, L., Popa, M.- Depoluarea solurilor contaminate cu produse petroliere, Lucrări de laborator, Editura UPG - Ploieşti, 2008, ISBN 978-973-719-243-1 